\title{
Power play: The dynamics of power and interpersonal communication in higher education as reflected in David Mamet's Oleanna
}

\author{
Peter Chiaramonte \\ Adler Graduate Professional School
}

\begin{abstract}
David Mamet's play Oleanna may be infamous for reasons that do not do justice to the play's real accomplishments. One reason for the controversy is the author's apparent focus on sexual harassment. The play is not about sexual harassment. It is about power. And in particular the power of language to shape relationships within social environments such as universities. First published and performed in 1992 - at a time when many were outraged by the Clarence Thomas - Anita Hill debate - the playwright himself was compelled to deny his play was about sexual aggravation. Mamet's Oleanna serves to instruct us about the power dynamics within one of our most vital institutions. The aim of this article is to take a dedicated look at this dramatic spectacle to see if we cannot uncover something about leadership and the mechanics of power and communication in higher education that is intellectually riveting, as well as socially constructive.
\end{abstract}

\section{Résumé}

La réputation d'Oleanna, pièce de David Mamet, ne rend pas justice aux accomplissements réels de l'œuvre. C'est qu'elle a suscité la controverse en traitant du harcèlement sexuel, du moins si l'on en croit tout ce qui a été écrit à son sujet. Erreur, puisque le thème est celui du pouvoir, en particulier du pouvoir du langage dans les relations au sein de nos grandes institutions sociales, comme les collèges et les universités. Après la présentation initiale en 1992 (pendant le scandale entourant l'affaire Clarence Thomas-Anita Hill), l'auteur a nié avoir écrit sur le harcèlement sexuel. Reposant sur le jeu de deux 
acteurs, la pièce en trois actes ratisse plus large. Elle révèle la dynamique du pouvoir dans l'enseignement supérieur, un fleuron institutionnel. Notre analyse porte sur le regard stimulant et constructif que pose Mamet sur ce milieu : ses instances dirigeantes, son évolution, sa mécanique du pouvoir et ses communications.

All theatre is necessarily political; because all the activities of man are political and theatre is one of them ... the theatre is a weapon. A very efficient weapon ... it is, in effect, a powerful system of intimidation.

- Augusto Boal, Theatre of the Oppressed

\section{Crisis, What Crisis?}

Perhaps no other twenty-first century institution in society has as great a potential for shaping the lives of its constituents as does the university. Sooner or later, everyone will have a vested interest in how we advance to the highest academic degrees. Everyone has a concern with how well our society qualifies new generations of professionals in every field that exists, as well as those still to be imagined. But is society getting its money's worth in terms of the resources it takes to accomplish these aims? It appears that more than a few unemployed and under-employed university graduates are feeling stung by the prospect of having little to show for what they borrowed heavily to get (Arum \& Roksa, 2011; Coté \& Allahar, 2011; Fallis, 2007; Pocklington \& Tupper, 2002; Slaughter \& Rhoades, 2004; Woodhouse, 2009). What sequels to such plots?

Each of the above authors does a good job of reporting the news - but now is the time for going past words - and aiming to make the fundamental changes that institutional leadership for the twenty-first century will require. For example, I believe there is good reason to examine David Mamet's Oleanna, while keeping in mind the work of Brazilian theatre artist and social activist, Augusto Boal. If we take account of the core ideas practised in Boal's Arena Theatre, it might help us to frame ongoing debates about gender politics and sexual harassment in a broader light and help us to act upon that stage.

In a discussion of Oleanna, if a critical approach to the play is sympathetic to the character of the student Carol, critics typically interpret the play with gender politics as their focal point (Kulmala, 2007, p. 118). If sympathetic to John, the professor, they address issues of power, language, or education as the basis of their interpretation (Bean, 2001; Murphy, 2004, p. 126; Sauer \& Sauer, 2004, p. 225-26). There is no right or wrong perspective. But from an organizational-communication perspective, any of the dichotomies defaulted to out of habit can be recast, to echo the power dynamics shaping and being shaped by the institutional circumstances in which each of the players finds themselves.

Rather than exclusively attributing motive behaviour to individuals, maybe we should be taking a closer look at the dynamic social contexts in which individuals find themselves situated. Or as one reviewer put it, "to examine how the institution turns both Carol and John into vicious animals!" With this perspective in mind, we can pause the action and pose a few basic questions. For example, why do you or don't you think the university, as an institution, might be in some sense responsible for turning both students and profes- 
sors into brutal animals? And what do you think could be done to change this if it is true? Perhaps we should begin these ruminations with a synopsis of the play to look for clues in this endeavor.

\section{Synopsis of Oleanna}

Who or what is "Oleanna?" This two-person, three-scene play gets its title from a nineteenth-century Norwegian folk song about New Norway, a community established in the northern mountains of Pennsylvania in 1852. The song was translated and recorded by folksinger Pete Seeger a century later. The lyrics concern the singer's desire to leave Norway and escape to a New Norway, a place they called Oleanna, where

The women there do all the work

As 'round the fields they quickly go

Each one has a hickory stick

And beats herself if she works too slow. (Anon, 1936 n.d.)

The American businessmen who sold the land to naïve Norwegian immigrants in the mid-nineteenth century reserved the best land for themselves, of course. By 1857 the entire community of New Norway was destroyed by good old-fashioned capitalist fraud, and the Norwegians had no way to survive what they initially hoped would turn out to be a utopian dream come true (Breyer, 2009, p. 5). The dream of Oleanna became a dream abandoned. A dropout without tenancy.

In the first scene of the play, John - a university professor, husband, and father in his mid-forties - is on the verge of achieving tenure. He is meeting his twenty-year-old student, Carol, in the tight confines of his office. Carol has come to discuss the professor's course in education, which she is struggling with. Their conversation is repeatedly interrupted by telephone calls from John's wife, presumably calling to talk about the new house they are in the process of buying. John proposes that Carol come back to meet with him some other time. Just as she is about to leave, the phone rings again - this time precisely at the moment Carol appears on the brink of revealing some mysterious secret about herself. Carol subsequently deciphers John's touching her on the shoulder as a sexual assault, which may indicate there is more stirring beneath the Earth's crust than she is ever given the opportunity to disclose.

To varying degrees, for the remainder of the play, Carol accuses John of sexual harassment and even rape after he attempts to interfere with her leaving his office because of some dreadful misunderstanding, according to the professor.

Things end tragically, especially for John. His troubles may have begun long before Carol's accusations of impropriety. What we know for sure is that John's dreams of tenure and a new house for his family have vanished by the end of the play, along with his job and perhaps much more. He has lost everything. In the final scene, Carol, with the backing of her "Group," gives John a list of books she and her Group want banned, including a book that he himself has authored. Even then, Carol is again left waiting in his office while her professor is distracted by yet another telephone call from his wife. It is then Carol coolly whispers, "Don't call your wife 'Baby" - at which point John becomes completely unglued, and lets loose the hounds and bawls: 
You vicious little bitch. You think you can come in here with your political correctness and destroy my life? (He knocks her to the floor.) After how I treated you ...? You should be ... Rape you ...? Are you kidding me...? (He picks up a chair, raises it above his head, and advances on her.) I wouldn't touch you with a ten-foot pole. You little cunt ... (p. 79-80).

No one can deny the brutal viciousness of the attack; however, exclusive focus on the physical and emotional violence of this climax overwhelms other relevant considerations that led to it - thus clouding aspects of the script that deserve close attention from the audience. Here I would invite students, parents, campus staff, and professors to have a closer look at critical responses over the years to Mamet's tragic drama. Then, with purpose, reconsider the reflections of university life portrayed in Oleanna with the Brazilian activist director Augusto Boal's perspective and procedures that he used in his Arena Theatre productions.

\section{Oleanna, and Boal's Theatre of the Oppressed}

Critical response to David Mamet's Oleanna has been stridently divided for decades, ever since the play's original debut. One group of critics in particular has repeatedly denounced the author for what they perceive to be an arrant over-simplification of gender politics and sexual transgression. Since the play's unveiling at the American Repertory Theater in Cambridge, Massachusetts, on May 1, 1992, many feminists have indicted Mamet for depicting the character of women primarily as manipulative. Nor has it been uncommon during productions of the play for some audience members to hiss at Carol and cheer in the end when John beats her onstage. But not everyone sees the same thing when they go to the theatre.

Several critics have protested that the playwright's characterization of Carol deliberately alienates her from the audience. Still, there have been other commentators who commend Mamet for what they perceive to be a valuable exposé of the interplay of power, language, and oppression in our society. Another faction defends the author for his shrewd literary account of the complexities surrounding specific abuses of power in academic circles. However, in one other particularly pained critique, Elaine Showalter concludes, "Mamet has written a polarizing play about a false allegation of sexual harassment, and that would be fair enough - false allegations of harassment, rape, and child abuse indeed occur - if he were not claiming to present a balanced Rashomon-like case" (Showalter, 1992, p. 16). Oh I see, now the mudslinging really begins. I am sorry, Ms. Showalter, I missed that part. I never read where Mr. Mamet claimed any such thing. You need to show me.

All constituents in higher education should and do, I hope, have a serious concern for academic freedom. We all share a common interest in reducing both the incidence of sexual harassment false allegations. In some cases, for example when the Tennessee Technological University staged a production of Oleanna in the winter of 1996, the director and associate professor of theatre, Mark Creter, reported one colleague telling him, "I wanted to get up on stage and kill the bitch myself" (Breyer, 2009). Tempers can run high on both sides. And theatre is, I believe, the perfect arena in which to sublimate such passion into action, only we need to thoroughly understand it first. 
One way to approach the power dynamics in this play is from the perspective of $\mathrm{Au}-$ gusto Boal, a Brazilian director and political activist, who suggested we treat the situation such as found in Oleanna "as a dialogue and as an opportunity to act out social change." Boal was also well known for quoting Shakespeare's Hamlet - especially arguments the young Prince of Denmark makes about theatre being like a mirror, which one can reach in to, "to change reality by transforming" it. Boal (who died in 2009), drew on famed Brazilian educator Paulo Freire's seminal Pedagogy of the Oppressed (1970) for inspiration on effecting transformative change. So might we (before Fortinbras figuratively enters the stage and our final curtain falls). Freire's earlier work signaled for new relationships between teachers, students, and societies, which he saw emerging throughout the sixties. It was from this new-found commitment to democracy and education that Boal developed his Theatre of the Oppressed (first published in English in 1974) to reflect his ongoing concerns as well as a desire to overcome the terrible implications of what Freire famously (and disparagingly) referred to as the "banking model" of learning.

\section{"Don't Follow Leaders - Watch Your Parking Meters..."}

The so-called "banking model" is a metaphor for the way schools and education systems treat students - as if they were empty vaults into which teachers can deposit knowledge as casually as one would toss coins into a wishing well. Rightly opposed to such an approach, Freire and legislativonistas like Boal proposed a new pedagogy that combined community theatre with social activism. Each dealt with their constituents - whether they were parents, teachers, regular theatregoers, or just kids in the street - as partners in the creation of knowledge. Others have acted upon such themes with great effect in summer parks and amphitheaters, and so could we.

"In the 1950s," Augusto Boal told journalist Juan Gonzalez (June 3, 2005),

I did theatre like everybody else in that you call the spectator to come ... charge a price for the ticket ... and do the best that you can. But soon I understood, "Okay, it's nice," and then they went away and nothing else happens. And always for me theatre should be more than that.

Boal went on to explain how his open forum Arena Theatre approach works: "We present the problem because sometimes we know what the problem is ... we all agree we have this problem ... But how to do it [solve the problem] we don't know." In Arena Theatre, whatever the theme, the spectators as well as the actors join together to explore various ways the group can tackle solutions to their problem from different perspectives - as collaborators - with no one acting eminently higher than any other. "Everything in society is going to change regardless." Boal simply asks, "So, why not see if we can change things for the better?" (Gonzalez, June 3, 2005).

In Arena Theatre, we can invite students and professors from the audience to replace the protagonists, Carol and John, in the play. Then experiment with alternative scenarios. In this way we, the audience, would continue to learn from one another's ongoing performances. The purpose is to understand what the best, if not all universities should be doing all along - developing the capacity of individuals and groups to fully enrich each other's sensibility. 
No one really - not even if they were not the least bit aware of the alternatives available - wants to live in a world where they either take or issue orders all of the time. People want and deserve nobler alternatives than that. If we venture to add leadership, courage, and a modicum more imagination to our purpose, we can create better options. Ironically, those furthest remote from what really goes on in the face-to-face classrooms and consulting rooms of academe are the administrators who either govern what is taking place or vouch to protect us from it. So what can be done to improve matters - aside from handing out chainmail seat cushions at graduation, with the insignia, Couvrez votre âne? Personally, I'd be more enthused to take another look at Oleanna and other dramatic reveries like it instead.

\section{Sexual Harassment Will Always Be as Politically Charged in the Theatre as in the University}

Since sexual harassment is undoubtedly an obstruction to women (and gay minorities) seeking access to higher education or better employment opportunities, there are many good reasons we need to ensure that adequate provisions for due process are in order. On the other hand, extreme advocates of feminism and political correctness might be doing a disservice to both the accuser and the accused. For instance, if they were to advance exaggerated claims by making too much of minor incidents, they would be undermining the seriousness of the matter on both sides. For example in Oleanna, Carol's character immediately loses support from the audience when she likens a negligible episode in the first scene to rape. Then she loses support again when she pushes her Group's censorship agenda in the exchanges building to the brutal climax of the play. Abuses of power from either side need not delight everyone in the audience in order to be effective as dramatic points of spectacle and institutional debate.

Carol: You tried to rape me. (Pause) According to the law. (Pause)

John: ... what ...?

Carol: You tried to rape me. I was leaving this office; you "pressed" yourself into John: .... I ... me. You "pressed" your body into me.

Carol: My Group has told your lawyer that we may pursue criminal charges. (p. 77-78)

Carol's invisible Group acts as a kind of phantom Medusa advancing from backstage and spreading rumors even she isn't able to make out clearly beyond her own reflections. Carol's Group represents the aspirations of many students to the very ideals of absolute truth in education, a truth that John fervently snubs. Therein lies the rub. Mentioning "criminal charges" to a professor in this context is akin to grinding shards of glass into an open wound. Violence doesn't necessarily involve physical force. Angry words viscerally expressed can break your bones as well as any sticks and stones could. Destructive energy impulses directed at intimidating the emotions will suffice as violence whichever way you are prone to tag it. Calling Carol a "cunt" or John a "rapist" may not prove anything one way or another. But it could make for a lively debate in the after-party discussion.

Literary critic and playwright Janet Ruth Heller tried putting the boot into the discussion by arguing David Mamet is, with Oleanna, somehow "[indicting] feminism as 
mindless, inherently manipulative, and hostile to men" (Heller, 2000, p. 93). On the contrary, I would argue that Carol's character is not a feminist at all. Having carefully read and seen the play several times, I cannot find a single incidence where Carol mentions "feminism," or identifies herself or her Group as "feminist." University of Connecticut professor Brenda Murphy incisively remarks that, "Carol does not object to authority or to the institutions that wield power, she simply wants access to them. Carol's objection to John is that he tries to deny that he is wielding power and is making her feel bad for doing so" (Murphy, 2004, p. 131). Professor Murphy's interpretation makes more sense to me than some of the others. For instance, one can readily see that even as Carol tussles to express herself, she may be revealing undercurrents that lay invisible to her, as to many of us much of the time.

Carol: No. No. There are people out there. People who came here. To know something they didn't know. Who came here. To be helped. To be helped. So someone would help them. To do something. To know something. To get, what do they say? "To get on in the world." How can I do that if I don't, if I fail? But I don't understand. I don't understand. I don't understand what anything means ... and I walk around. From morning 'til night: with this one thought in my head. I'm stupid. (p. 12)

Carol sounds to me, as one might suppose some of today's students still do, as if she wants to be fed knowledge and information as opposed to hunting and gathering it for her own. John's glib attitude toward this is, "It's just a course, it's just a book" - simply by-products in this sorry business we call higher education. No big deal. Nothing to get your skirt in a twist over. Carol expects that her investment in college education will "open new doors" as they say, whereas John's teaching philosophy and methods have it in mind to free generations of teachers from such mundane concerns. Perhaps I'm giving him too much credit, or not enough. Maybe it's fairer to say that Carol wants answers that John does not, cannot, or will not provide. Are such matters relevant and worth discussing when thinking about the present culture of higher education, or what difference would that make? There's only one way to find out.

\section{The Politics of Language in Higher Education}

Carol: My charges are not trivial. You see that in the haste, I think, with which they were accepted. A joke you have told, with a sexist tinge. The language you use, a verbal or physical caress, yes, yes, I know, you say that it is meaningless. I understand. I differ from you. To lay a hand on someone's shoulder.

John: It was devoid of sexual content.

Carol: I say it was not. I SAY IT WAS NOT. Don't you begin to see...? Don't you begin to understand? IT'S NOT FOR YOU TO SAY. (p. 70)

We can't impute the students for this sorry mess. They have been led to feel entitled. Politically - socially - intellectually we have all been fed a crock. Oleanna is an indictment of an academic culture and needless ranking as much as anything else. (In what other occupation do we have three different job titles for the exact same job?) A culture 
in which stratified power roles and language games oftentimes make teaching injurious and learning intolerable. And what about professors and administrators bearing some responsibility for this current state of affairs? Right from the beginning of the play, John uses what every schoolgirl and schoolboy immediately recognize as the condescending tone of scholarly language, clearly meant to establish superiority. There again, in the second scene, when Carol begins to have some leverage against him, John still feels he can dissuade her by using his finely developed rational ability. In the end, however, when he has lost all supremacy and appears to have been desecrated by his defeats, John is reduced to physically lashing out like an "unthinking animal." Whereas Carol has mysteriously calmed (Cengage, 2005, p. 3). While he rants and barks, the underdog quiets herself down into a snarl.

The power of language (not only what you say, but how you say it) is always front and centre from beginning to end in all David Mamet's theatre plays (e.g., Speed the Plow, The Poet and the Rent, Glengarry Glen Ross, American Buffalo, A Life in the Theatre, Sexual Perversity in Chicago, and The Duck Variations, to mention a few.) From the start of Oleanna, John never hesitates to let Carol know where she stands in his priorities. Like so many of us, he talks more than he listens. He repeatedly cuts Carol off in mid-sentence. And just when she is about to reveal an important secret about herself, he dismisses her by answering his phone. Over and over again throughout the play John never once bothers to validate any of Carol's feelings, but insists she has misinterpreted him. In the final exchange, he objectifies her by using a crude epithet, which reduces her to a mere body part. When that doesn't work, he resorts to dragging his thwacked knuckles on the floor.

Not only does Carol gain remarkable proficiency in language throughout the middle and final scenes of the play, but also she uses this proficiency to gain power over John. Not only does John's language deteriorate into fragments and curses, but Carol employs the very same words to dismantle his defenses. On one level, by letting his guard down - by his arrogant expression of uncensored thoughts - John has inadvertently taught Carol an indispensable lesson in the power of language and how to wield it. In a Mamet play, any character that allows himself to be vulnerable or exposed when it comes to interpersonal communication becomes a loser in this house of games. For example, in Scene 2 of Oleanna:

Carol: ...You confess. You love the Power. To deviate. To invent, to transgress ... to transgress whatever norms have been established for us...And you pick those things which you feel advance you: publication, tenure, and the steps to get them you call "harmless rituals." ... Although you say it is hypocrisy ... you have no idea what it cost me to come to this school - you mock us ... And ask me to understand that you have aspirations too. But I tell you ... That you are vile. And that you are exploitive. And if you possess one ounce of that inner honesty you describe in your book, you can look in yourself and see those things that I see. And you can find revulsion equal to my own ... (p. 52)

And again in Scene 3:

John: They're going to discharge me. 
Carol: As full well they should. You don't understand? You're angry? What has led you to this place? Not your sex. Not your race. Not your class. YOUR OWN ACTIONS...You want to "charm" me. You want to "convince" me. You want me to recant. I will not recant. Why should I...? What I say is right...You are going to say that you have a career and that you've worked for twenty years for this. Do you know what you've worked for? Power. For power. Do you understand? (p. 64-65)

If ordinary miscommunication is a sock on the jaw, then the politics of language in Oleanna's final sequence is more like a kick in the groin. Simply the accusation of sexual misconduct leveled against a faculty member in most universities will result in the accused being persecuted, shunned, and sent home. Permanently. More than twenty years of schooling (plus another five or more in the trenches) and what does that get him? A one-way ticket to Palookaville. One wonders what sort of a grade John finally gave Carol for the course.

\section{The Political Currency of Anguish}

All-purpose perceptions of a university education's "cash value" - if self-promotion in television and subway advertising are to be trusted - are that things will "pay off" in terms of satisfying all the personal, economic, and social interests it is presumed to augment. Popular beliefs about the veracity of such arrangements vary greatly. One issue for higher education in general might be how institutional culture and communications condition our expectations and patterns of interaction. For instance, one might ask how organizational conditions contour relationships in which students and professors are actively or inactively engaged. Professor of higher education, George Kuh has examined this notion of, "I'll leave you alone if you leave me alone" - arguing that a mysterious "disengagement compact" has been entered into by faculty and students on many campuses (Kuh, 2003). What, if anything, can help us to understand this status quo of detachment? Perhaps there are - among the causes and challenges - signs and signals that things could be made a whole lot better, though not easily anytime soon.

University of Reading Whiteknights lecturer Christine MacLeod considers the very nature of capitalism itself to be the culprit, forcing John and Carol to act in their own self-interest, using the "control of language" to attack each other in order to survive (MacLeod, 1995, p. 202). That's plausible. But it might be a stretch to imagine the collapse of the capitalist market system momentarily. Other scholars have also addressed the matter of language and the misuse of power in specific academic settings (Garner, 2000; Silverstein, 1995; Skloot, 2001). For example, Brenda Murphy focused on the use of "specialized language" as a means of gaining entry into "restricted linguistic communities that confer power, money, and/or privilege upon their members" (Murphy, 2004, p. 126). What can fairly be done in the meantime while we ask students to wait in the lobby?

In the play Oleanna, Carol expresses the belief that the purpose of higher education is to pursue absolute truths; that if she works hard enough, takes copious notes, and plays by the rules she will obtain these truths for herself (Kulmala, 2007, p. 107). The conflict between John and Carol is not only exacerbated by the professor's insistence that such truths are ultimately based on illusions, but also by the illusory circumstances the rules 
themselves create. To Carol, John is not doing what he was told - at least not according to her understanding of his obligations in the role of professor. She imagines that the superior authorities he derides will have his badge unless he tows the company line. As John attempts to explain that a gratuitous hierarchy exists - one in which they must both perform arbitrary rituals and make-believe appropriate expressions for their different roles - he only compounds Carol's anger and confusion. What might be done about that, I wonder? Besides caving in or playing along.

According to John, the entire field of higher education is itself a cultural fabrication that currently operates like any Walmart - relying upon large-scale production, tax breaks, and careful inventory control to sustain itself. Thus he expresses nothing but contempt for the tenure committee overseeing his promotion up the ranks of such a Mafialike syndicated sham. "Why, they had people voting on me I wouldn't employ to wax my car," he says. And about test-taking and grading: "Look," he tells her, "the tests ... which you encounter ... in college, in life, were designed, in the most part, for idiots. By idiots... They are not a test of your worth. They are a test of your ability to retain and spout back misinformation" (p. 23). One irony here is that talk is cheap, although deadly, and John does not always practice what he preaches. As a result, his philosophy of education comes off as unfathomable and arrogant. Rather than helping Carol, John first ignores her, then insults her, and then - after she fights back with the very linguistic weapons he used on her in the first place - he physically assaults her. Carol's most ardent jeers come after a thoroughly routed John is left whimpering, "Don't you have feelings?"

Carol: That's my point. You see? Don't you have feelings. Your final argument. What is it that has no feelings? Animals. I don't take your side, you question if I'm Human ... I have a responsibility ... To? This institution. To the students. To my group ... Because I speak, yes, not for myself. But for the group; for those who suffer what I suffer ... Who the hell do you think that you are? You want a post. You want unlimited power. To do and to say what you want. As it pleases you - Testing, Questioning, Flirting...

John: I never...

Carol: Excuse me, one moment, will you?

(She reads from her notes.)

The twelfth: "Have a good day, dear."

The fifteenth: "Now, don't you look fetching ..."

April seventeenth: "If you girls would come over here ..." I saw you. I saw you, Professor ... You asked me here to explain something to me, as a child that I did not understand. But I came here to explain something to you. You Are Not God. You ask me why I came? I came here to instruct you.

(She produces his book.)

And your book? You think you're going to show me some "light?" You "maverick." Outside of tradition. No, no, (She reads from the book's liner notes) "of that fine tradition of inquiry. Of Polite skepticism"...and you say you believe in free intellectual discourse. YOU BELIEVE IN NOTHING ... NOTHING AT ALL.

John: I believe in freedom of thought. (pp. 66-67) 
Carol, at this point in the final scene, thinks it incredulous that John would for one moment question the tenure committee's decision for refusing him tenure and issuing an immediate suspension. After all, from Carol's point of view, he was obviously guilty of mocking the very institutional system that granted him power in the first place. John was also guilty of not thinking too much of Carol and letting her know it. "I know what you think I am," Carol taunts an already vanquished foe.

Carol: You think I am a frightened, repressed, confused, I don't know, abandoned young thing of some doubtful sexuality, who wants power and revenge. (Pause) Don't you? (Pause)

John: Yes. I do (Pause). (p. 67)

\section{Palavras Passadas (Past Words)}

In 2009 at the Golden Theatre in New York, long after the final curtain fell, the producers of Oleanna took advantage of the play's controversial power to encourage animated conversations and community action among its theatregoers. How hard would it be to try something like that on our campuses every now and again? Why not hold a few regular "talk back" forums with members of the audience, invited guests, actors (some of whom could remain in character) - and maybe have experienced Arena Theatre directors coaching the crowd and conducting the chorus. Here is some of what I can imagine us talking about: Is this play primarily about the war of the sexes, or is it something else? Is there a crisis in higher education - or is it all theatre? - just something someone has made up? Is the system working? Do these reflections of Mamet's refract or reveal your subjective experience of university life? Was the professor sexually attracted to Carol in the first scene? Does it matter? Is Carol an abandoned young thing of some doubtful sexuality, and if so, what does this have to do with the main premises of the play? What would you guess is her secret? Is the institution somehow to blame for this sort of tragedy? Does John deserve to be denied tenure? Is he justified in knocking Carol to the floor and advancing on her with a chair raised high above his head? And so on. Does the university structure and the environment itself somehow transfigure its members into backbiting primates, or is that going too far?

At the conclusion of any drama it all comes down to the perceptions of the audience, doesn't it? For students and professors - Oleanna is a play within a play - the meaning of which bounces off the senses within each individual's imagination. These mirroring effects may be akin to stepping through a looking glass and - after stepping back again finding that the image we once had of ourselves has been transformed by the experience. Let's not guess - let's ask them. Such is the power of the theatre and the classroom. Or, is it the theatre as classroom?

In their book, Lowering Higher Education: The Rise of Corporate Universities and the Fall of Liberal Education (2011), Western University sociologists James Coté and Anton Allahar concluded that unless some broad-based social paradigm shift occurs, university degrees will soon become little more than expensive "fishing licenses" for fishedout lakes, rivers, and streams. Still, there's no end to the number of credentials neophytes can get with easy loans and government grants. Even if, after four years, graduates find themselves in a spot where neither the promise of wisdom nor the guarantee of a lucrative career is a foreseeable outcome. 
The crisis in higher education didn't just happen overnight. Nor will it be solved overnight. Or perhaps even in decades. The slow pace and unwieldy inertia of academic cultures, in my opinion, precludes any revolutionary turning away from the hegemonic corporate interests presently ruling the roost. Let's be candid. For all the investment that goes into building commercial theatre space, hockey arenas, coliseums, and gambling casinos - one would think that government ministry and campus officials could discover a way to stage a little self-reflection from time to time. Surely an idea like Arena Theatre wouldn't be too far out or bizarre for an institution that continually boasts being on the cutting edge of innovation? Let's invite the entire university community to take part in face-to-face theatrical forums, instead of gazing at tiny screen images of each other that we fondle with our thumbs.

Personally, I love the university and the live theatre and I'd like to see them both get along and work together. I'm all for enlightened social change and not just dragging chains for the business of higher entertainment. Just as I'd like not to see the real life reflections of students and professors like Carol and John have to duke it out that way night after night - psychically and socially disabled from showing genuine respect for one another. Yes, what is portrayed as happening in Oleanna is real enough and shocking, but also inevitable. Just let's look at the institutional circumstances!

Every time I've come away from a David Mamet play I've kept that wonderful, eerie sense that I've taken part in a genuine classic - a dramatic spectacle of epic stature within "my self." With Oleanna, the playwright presents us with a tragic reflection for our times that - dare I say - one can liken to Sophocles' Oedipus the King. Now that particular tragedy opens with Oedipus, the ruler of Thebes, lamenting the plague that has blighted his dominion. In Mamet's Oleanna, the vicious plague infecting the academic equivalent of Thebes (New Norway U.) may just be the budget officers who run the place. Swarms of harried carpetbaggers are actively selling college loans to dreamy-eyed secondary school grads and their parents, while increasingly remote, contingent faculty study each other's columns, graphs, and charts. Everyone looks miserable half the time, yet students are encouraged to go on smiling - expecting the entitlements of a promising future and, just maybe, some kind of intrinsically rewarding experience of lasting value. "Oh, to be in Oleanna."

Some people will go to the theatre to see David Mamet's play about Oleanna with similar expectations as those of us who went away to university with stars in our eyes and songs in our hearts. I've heard of campus productions of Oleanna where the audience left the theatre quarrelling every night with each other about all sorts of things. I have witnessed student audiences come away feeling more disturbed than disappointed. Some will be challenged to hang around after the final curtain falls and go on thinking together out loud about creating worthier institutional environments for themselves and others to take part in. Stepping through a glass darkly won't be easy. If it were easy, then anyone could do it. But no, that's not the academy for us. That's not the place we came to act in, witness or applaud "As 'round the fields [we] quickly go ..." [Exeunt]. 


\section{References}

Anonymous, n.d. "Oleana" (Norwegian folk song). Pete Seeger (1955) (trans.).

Arum, R., \& Roksa, J. (2011). Academically adrift: Limited learning on college campuses. University of Chicago Press.

Bean, K. (2001). A few good men: Collusion and violence in Oleanna. In C. Hudgins \& L. Kane (Eds.), Gender and genre: Essays on David Mamet. New York: Palgrave, 109123.

Boal, A. (1985). Theatre of the oppressed. New York: Theatre Communications Group.

Breyer, C. (2009).'Political correctness' and the university: The culture wars. (1992). Between the lines.

Cengage, G. (2005). Oleanna. David Mamet. Retrieved from http://www.enotes. com/oleanna-criticism/

Coté, J.E., \& Allahar, A.L. (2011). Lowering higher education: The rise of corporate universities and the fall of liberal education. Toronto: University of Toronto Press.

Fallis, G. (2007). Multiversities, ideas and democracy. Toronto: University of Toronto Press.

Freire, P. (1970). Pedagogy of the oppressed. New York: Continuum International.

Garner, S.B. (2000). Framing the classroom: Pedagogy, power, Oleanna. Theatre Topics, 10, pp. 39-49.

Gonzalez, J. (June 3, 2005). Interview with Augusto Boal: Theatre of the oppressed. Retrieved from www.democracynow.org

Heller, J.R. (2000). David Mamet's trivialization of feminism and sexual harassment in Oleanna. Midamerica, 27, 93-105.

Kuh, G.D. (2003). What we are learning about student engagement. Change, 35, p. 28.

Kulmala, D. (2007).'Let's take the mysticism out of it, shall we?': Habitus as conflict in Mamet's Oleanna. Journal of Dramatic Theory and Criticism Spring 2007, 101-121.

MacLeod, C. (1995). The politics of gender, language and hierarchy in Mamet's Oleanna. Journal of American Studies, 29, 199-213.

Mamet, D. (1992). Oleanna, a play. New York: Random House.

Murphy, B. (2004). Oleanna: Language and power. In C. Bigsby (Ed.), The Cambridge companion to David Mamet. Cambridge, UK: Cambridge University Press.

Pocklington, T., \& Tupper, A. (2002). No place to learn: Why universities aren't working. Vancouver, BC: University of British Columbia Press.

Sauer, D., \& Sauer, J.A. (2004). Misreading Mamet: Scholarship and reviews. In C. Bigsby (Ed.), The Cambridge companion to David Mamet. Cambridge, UK: Cambridge University Press.

Showalter, E. (November 6, 1992). Acts of violence. Times Literary Supplement. 
Silverstein, M. (1995). 'We're just human': Oleanna and cultural crisis," South Atlantic Review, 6o, (2): 103-20.

Skloot, R. (2001). Oleanna, or the play of pedagogy. In C. Hudgins and L. Kane (Eds.), Gender and genre: Essays on David Mamet. New York: Palgrave.

Slaughter, S., \& Rhoades, G. (2004). Academic capitalism and the new economy. Baltimore: Johns Hopkins University Press.

Woodhouse, H. (2009). Selling out: Academic freedom and the corporate market. Montreal: McGill-Queen's University Press.

\section{Contact Information}

Peter Chiaramonte

Faculty of Leadership and Organization

Adler School of Professional Psychology

razorsedge@me.com

Peter Chiaramonte is a native of Toronto who studied philosophy and education at Ohio University and the University of Toronto, where he earned his BA and BEd degrees. Peter completed his PhD in the Graduate School of Education at the University of California, Santa Barbara (UCSB). That program in Confluent Education at UCSB originated with a Ford-Esalen Foundation project grant at the Esalen Institute in Big Sur. It was there Peter began exploring psychodramatic techniques for arousing spontaneous leadership in higher education. Dr. Chiaramonte is currently affiliated with the Adler Graduate Professional School's new Faculty of Leadership and Organization. 